\section{Growth Response of Rose Geranium (Pelargonium graveolens L.) to Calcium:Magnesium Ratio, Magnetic Field, and Mycorrhizae}

\author{
Neo Edwin Nyakane and Moosa Mahmood Sedibe \\ Department of Agriculture, Central University of Technology, Free State, \\ Private Bag x20539, Bloemfontein 9300, South Africa
}

Elisha Markus

Department of Electrical, Electronic and Computer Engineering, Central University of Technology, Free State, Private Bag x20539, Bloemfontein 9301, South Africa

Additional index words. amendments, chlorophyll contents, hydroponic, mineral composition, recirculating system, split-plot

\begin{abstract}
The objective of this study was to evaluate the effects of the Ca:Mg ratio, magnetic field (MF), and mycorrhizal amendment on the yield and mineral composition of rose geranium. The experiment was structured as a $3 \times 2$ factorial experimental design, with three levels of the $\mathrm{Ca}: \mathrm{Mg}$ ratio $\left(2.40: 6.78,4.31: 4.39\right.$, and 6.78:2.40 meq. $\left.\mathrm{L}^{-1}\right)$, 6.78 Ca:2.40 Mg meq. $\mathrm{L}^{-1}$ denoted by "High-Ca:Low-Mg," equal proportion of Ca and $\mathrm{Mg}$ (4.31 Ca:4.39 Mg meq. $\mathrm{L}^{-1}$ ) represented by "EP-Ca:Mg," and $2.32 \mathrm{Ca:6.38} \mathrm{Mg}$ meq. $\mathrm{L}^{-1}$ denoted by "Low-Ca:High-Mg," two levels of MF (no MF, denoted by "0 MF," and $110 \mathrm{mT}$, denoted by " $1 \mathrm{MF}$ ") and split treatments of mycorrhizae (zero mycorrhizae denoted by "0 Myco," and $20 \mathrm{~mL}$ mycorrhizae denoted by "1 Myco") were used in this study. The results show that the plant height and branch dry mass were significantly $(P<$ 0.05) affected by the Ca:Mg ratio. No significant effect of $\mathrm{Ca}: \mathrm{Mg}$ ratio, MF, or mycorrhizae on the number of leaves, foliar mass, leaf dry mass, or yield was detected. Phosphorus, $K, S, F e$, and $B$ accumulation in the stem were unaffected, as were leaf $N$, $P$, $\mathrm{K}, \mathrm{Ca}, \mathrm{S}, \mathrm{Fe}, \mathrm{B}$, and $\mathrm{Cu}$. However, some agronomic attributes (plant height, number of branches, root length, and chlorophyll content) and mineral composition (Stem-N) were optimized when the 1 MF exposed nutrient solution was used with about equal proportions of $\mathrm{Ca}$ and $\mathrm{Mg}$. This $\mathrm{Ca}: \mathrm{Mg}$ ratio in the nutrient solution, together with the exposure of rose geranium plants to $1 \mathrm{MF}$, yielded positive results. The findings of this study can be applied to improve the production of rose geranium by enhancing the growth and mineral concentration of this crop.
\end{abstract}

The fundamental goal of applying fertilizers is to supply nutrients that are essential for crop growth and increased yield. Crop yield is the basic factor that determines optimal fertilization (Ju and Christie, 2011). Therefore, it is important to apply fertilizers in an efficient way to minimize loss and to improve the nutrient use efficiency of crops (Yousaf et al., 2017). Correct application of nutrients may enhance crop quality, but oversupply can have harmful effects. For instance, oversupply of certain nutrients leads to reduction of seed formation by encouraging excessive vegetative growth (Patel et al., 2015). Mengel and Kirkby (2004) reported that fertilizer applied during the vegetative

Received for publication 24 May 2019. Accepted for publication 3 July 2019 .

This work was financially supported by the Central University of Technology, Free State, National Research Foundation (NRF) and the Free State Department of Education, South Africa.

M.M.S. is the corresponding author. E-mail: msedibe@cut.ac.za. synthesis. Calcium is also required for the stability and functions of cell walls (White and Broadly, 2003). Inadequate application of Ca has a negative impact on plants, leading to the collapse of cell walls (Sander and Andren, 1997).

Similarly, adequate $\mathrm{Mg}$ nutrition is required for root and shoot growth, in terms of biosynthesis and translocation of photo assimilates. Magnesium plays a critical role in phloem loading and transportation of photo assimilates into sink organs (Zhang and Turgeon, 2009). Plants with low Mg supply are very sensitive to light intensity and heat stress and can easily become chlorotic and necrotic, probably because of extensive production of reactive oxygen (Cakmak and Kirkby, 2008). There is limited information available on the effect that the $\mathrm{Ca}: \mathrm{Mg}$ ratio has on rose geranium production.

Biostimulation of crops with the external application of an MF as a way to improve plant physiology, as well as oil quantity and oil composition to meet geranium bourbon essential oil standards, has caught the interest of many scientists around the world. External MF application for the purpose of nutrient modification in microorganisms and biological systems is becoming an increasingly important technique as new evidence reveals the ability of plants and microorganisms to perceive and respond quickly to MF (Kordas, 2002; Occhipinti et al., 2014; Vanderstraeten, and Burda, 2012). However, the biological effects of MF treatments depend on the strength and exposure period of the plant to the MF. The interaction of an MF and exposure time indicate that a certain combination of MF and duration are highly effective in enhancing growth characteristics. However, there is still no clear indication of how MFs achieve such changes.

There is also a growing interest from hydroponic rose growers in biologically based approaches to plant production to reduce the utilization of high amounts of fertilizers and pesticides. Various studies have shown that application of mycorrhizae can improve growth and yield through improved nutrient uptake, particularly under conditions of limited water supply, lowquality irrigation water, low soil fertility, high daytime temperatures with high evapotranspiration rates, or soil salinity (AbdelRahman et al., 2011; Al-Karaki, 2000). Among the numerous benefits offered by mycorrhizae are increased absorption of mineral elements, which enhances a plant's defense against pathogens and drought conditions (Jeffries et al., 2003).

Therefore, the objective of this study was to evaluate the individual and combined effects of the $\mathrm{Ca}: \mathrm{Mg}$ ratio, MF exposure, and amendment with mycorrhizae on the yield and mineral composition of rose geranium.

\section{Materials and Methods}

The experimental trial was carried out in a $40 \mathrm{~m} \times 15 \mathrm{~m}$ greenhouse at the Glen College of Agriculture, located in the Mangaung 
Municipality in the Free State Province of the Republic of South Africa. The geographical position of the college is lat. $28^{\circ} 55^{\prime} \mathrm{S}$ and long. $26^{\circ} 19^{\prime} \mathrm{E}$ and an altitude of $1307 \mathrm{~m}$ above sea level. The study was conducted during the 2015/2016 growing season and was repeated during the 2017/2018 growing season. Transplanting took place in September, and harvesting was carried out in April for both seasons.

Rose geranium cuttings $( \pm 12 \mathrm{~cm})$ were transplanted in 5-L potting bags filled with sterile silica sand during the 2015/2016 and 2016/2017 growing seasons. A $230-\mathrm{V}, 18-\mathrm{W}$ Wortex fountain FP 15 water pump with a flow rate of $900 \mathrm{~L} / \mathrm{h}$ was used to fertigate experimental plants. The recirculating system had four dripper tubes allocated to four pots consisting of a single plant. The plants were irrigated twice a day for the first month, at 1130 and $1400 \mathrm{HR}$, in a closed recirculating irrigation system. The irrigation volume was gradually increased to three times a day, at 0800,1200 , and $1600 \mathrm{HR}$, to ensure that $10 \%$ to $15 \%$ of the water was leached out to reduce any build-up of salt in the root medium. The nutrient solution was replaced with fresh solution at 3-week intervals during the experimental periods.

Nutrient solutions were prepared to provide three levels of $\mathrm{Ca}: \mathrm{Mg}$ ratios (Table 1). Other micro elements were supplied in amounts of $6.54 \mathrm{~g} \mathrm{Fe}, 1.89 \mathrm{~g} \mathrm{~B}, 0.13 \mathrm{~g} \mathrm{Mo}$, $1.16 \mathrm{~g} \mathrm{Zn}$, and $2.11 \mathrm{~g} \mathrm{Mn}$ per $1000 \mathrm{~L}$ of water. $\mathrm{A} \mathrm{pH}$ level of 5.5 was maintained by adding $79 \mathrm{~mL}$ of $\mathrm{HNO}_{3}(60 \%)$ per $1000 \mathrm{~L}$ of water. The electrical conductivity was 1.55 $\mathrm{mS} \cdot \mathrm{cm}^{-1}$. The mycorrhizal strains used in this study were Mycoroot ${ }^{\mathrm{TM}}$ SuperGo products [Mycoroot $^{\mathrm{TM}}$ (Pty.) Ltd., Grahamstown, South Africa]. They consisted of five different species of arbuscular mycorrhizal isolates: Rhizophagus clarus, Gigaspora gigantea, Funneliformis mosseae, Claroideoglomus etunicatum, and Paraglomus occulum. Two north-facing magnets each weighing $56.4 \mathrm{~g}$ and each with a length and width of 4.5 and 2.0 $\mathrm{cm}$, respectively $(110.1 \mathrm{mT})$ were placed at the bottoms of 5-L potting bags used in the MF treatments.

Layout. Treatments were arranged in a completely randomized block design with three replications, using a $3 \times 2$ factorial design, with the mycorrhizal treatment applied in a split. Three levels of the $\mathrm{Ca}: \mathrm{Mg}$ ratio (2.40:6.78, 4.31:4.39, and 6.78:2.40 meq. $\left.\mathrm{L}^{-1}\right)$, 6.78 Ca:2.40 Mg meq. $\mathrm{L}^{-1}$ denoted by "High$\mathrm{Ca}: \mathrm{Low}-\mathrm{Mg}$," equal proportion of $\mathrm{Ca}$ and $\mathrm{Mg}$ (4.31 Ca:4.39 Mg meq. $\mathrm{L}^{-1}$ ) represented by EP-Ca:Mg, and $2.32 \mathrm{Ca}: 6.38 \mathrm{Mg} \mathrm{meq} \cdot \mathrm{L}^{-1}$ denoted by "Low-Ca:High-Mg," two levels of MF (no MF, denoted by "0 MF," and 110 $\mathrm{mT}$, denoted by " $1 \mathrm{MF}$ ") and split treatments of mycorrhizae (zero mycorrhizae denoted by "0 Myco," and $20 \mathrm{~mL}$ mycorrhizae denoted by "1 Myco") were used in this study.

Agronomic attribute measurements. Plant height, number of branches, number of leaves, root length, chlorophyll, leaf dry mass, branch dry mass, and root dry mass were measured at harvesting $(6$ months after transplanting). Foliar material was oven dried at $60{ }^{\circ} \mathrm{C}$ for $96 \mathrm{~h}$. The dried samples were milled (0.30-mm diameter), using a method described by Sedibe and Allemann (2013). The chlorophyll content was determined randomly from the upper six mature leaves on the crop using a portable nondestructive chlorophyll meter (CCM-200; Opti-Sciences, Hudson, $\mathrm{NH}$ ), following a procedure described by Chen and Black (1992). The chlorophyll content was determined at harvesting.

Mineral analyses. Mineral contents (N, P, $\mathrm{K}, \mathrm{Ca}, \mathrm{Mg}, \mathrm{S}, \mathrm{Fe}, \mathrm{Zn}, \mathrm{Cu}$, and $\mathrm{B}$ ) were measured separately for both leaf and stem samples using a Dumas combustion method (Etheridge et al., 1998; Matejovič, 1996) with a Leco FP-528 combustion nitrogen analyzer (LecoCorp, St. Joseph, MI).

Statistical analyses. The data collected were analyzed using the SAS statistical analysis software (SAS Institute, Cary, NC). Tukey's Student range test was used to separate means that were significantly different at $P<0.05$, as described by Steel and Torrie (1980).

\section{Results}

\section{Agronomic attributes}

Agronomic attribute data are shown in Table 2. Ca:Mg ratio had a significant effect on the number of leaves per plant, leaf, stem and the dry mass of the root. It can be seen from Table 2 that plants treated with equal proportions of $\mathrm{Ca}$ and $\mathrm{Mg}$ in the nutrient solution grew taller $(P<0.05)$ and had the highest number of leaves $(P<0.05)$, resulting in an increased dry mass of leaves $(P<0.01)$ and branches $(P<0.05)$. The interaction between the $\mathrm{Ca}: \mathrm{Mg}$ ratio and exposure to an MF field had a significant $(P<0.05)$ effect on the number of leaves produced by rose geranium. A smaller number of leaves (19/ plant) were obtained when rose geranium plants were exposed to $1 \mathrm{MF}$ using a nutrient solution containing Low-Ca:High-Mg than when nutrient solutions with EP-Ca:Mg and with High-Ca:Low-Mg 1 MF were used. A significant $(P<0.05)$ interaction effect between the $\mathrm{Ca}: \mathrm{Mg}$ ratio and $\mathrm{MF}$ was observed on plant height. Plants that were grown using a nutrient solution containing Low-Ca:High$\mathrm{Mg} 1 \mathrm{MF}$ and High-Ca:Low-Mg 0 MF were relatively shorter than plants grown using EP-Ca:Mg nutrient solution. Exposure of rose geranium plants to a $\mathrm{MF}$ of $110 \mathrm{mT}$ affected plant height significantly, with an increase in the number of branches and a longer root system. The interaction between $\mathrm{Ca}: \mathrm{Mg}$ ratio and 1 Myco had a significant

Table 1. Cations of nutrient solutions used to study effects of $\mathrm{Ca}: \mathrm{Mg}$ ratio, magnetic field, and mycorrhizal fungi on yield and mineral composition of rose geranium.

\begin{tabular}{lcccccccccc}
\hline & \multicolumn{7}{c}{ Ion ratios (meq· $\left.\mathrm{L}^{-1}\right)$} \\
\cline { 2 - 10 } Ratio & $\mathrm{Na}^{+}$ & $\mathrm{NH}_{4}^{+}$ & $\mathrm{K}^{+}$ & $\mathrm{Ca}^{2+}$ & $\mathrm{Mg}^{2+}$ & $\mathrm{NO}_{3}^{-}$ & $\mathrm{H}_{2} \mathrm{PO}_{4}^{-}$ & $\mathrm{SO}^{4=}$ & $\mathrm{Cl}^{-}$ & $\mathrm{HCO}_{3}^{-}$ \\
\hline High-Ca:Low-Mg & 0.54 & 1.00 & 5.30 & 6.30 & 2.40 & 10.18 & 1.60 & 3.20 & 0.28 & 0.40 \\
EP-Ca:Mg & 0.54 & 1.00 & 5.30 & 4.31 & 4.39 & 10.18 & 1.60 & 3.20 & 0.28 & 0.40 \\
Low-Ca:High-Mg & 0.54 & 1.00 & 5.30 & 2.32 & 6.38 & 10.18 & 1.60 & 3.20 & 0.28 & 0.40 \\
\hline
\end{tabular}

High-Ca:Low- $\mathrm{Mg}=6.78 \mathrm{Ca}: 2.40 \mathrm{Mg}$ meq. $\mathrm{L}^{-1}, \mathrm{EP}-\mathrm{Ca}: \mathrm{Mg}=$ equal proportion of $\mathrm{Ca}$ and $\mathrm{Mg}=4.31 \mathrm{Ca}: 4.39$ $\mathrm{Mg}$ meq. $\mathrm{L}^{-1}$, Low-Ca:High-Mg $=2.32 \mathrm{Ca}: 6.38 \mathrm{Mg}$ meq $\cdot \mathrm{L}^{-1}$.
$(P<0.05)$ effect on the chlorophyll content. Plants grown using EP-Ca:Mg 1 Myco had a better leaf chlorophyll concentration.

\section{Stem and leaf mineral composition}

Stem and leaf mineral composition results

\section{Stem mineral composition}

Nitrogen. The interaction between $\mathrm{Ca}: \mathrm{Mg}$ ratio, MF, and mycorrhizae had a significant $(P<0.05)$ effect on $\mathrm{N}$ accumulation in the stem. Table 3 shows that a relatively high $\mathrm{N}$ content accumulated in rose geranium stems that were fertigated with a nutrient solution with approximately equal proportions of $\mathrm{Ca}$ and $\mathrm{Mg}$, in conjunction with $1 \mathrm{MF}$ exposure where no mycorrhizae was applied (Fig. 1) compared with plants treated with High$\mathrm{Ca}$ :Low-Mg with or without MF or Myco, but not significantly different from plants grown a relatively Low-Ca:High-Mg $1 \mathrm{MF}$ 1 Myco treatment.

$\mathrm{Ca}, \mathrm{K}$, and $\mathrm{Mg}$. The ratio of $\mathrm{Ca}$ to $\mathrm{Mg}$ had a significant effect on the $\mathrm{K}(P<0.01), \mathrm{Ca}$ $(P<0.05)$, and $\mathrm{Mg}(P<0.05)$ concentrations in the stem. As Table 3 shows, mineral accumulation in the stem was significantly affected when $2.40 \mathrm{Ca}$ meq. $\mathrm{L}^{-1}$ was used with $6.78 \mathrm{Mg}$ meq. $\mathrm{L}^{-1}$. Calcium concentrations in the stem increased with High-Ca:Low-Mg ratio, but $\mathrm{Mg}$ concentrations decreased concurrently. Potassium concentration in the stem decreased when $\mathrm{Ca}$ and $\mathrm{Mg}$ were applied in equal proportions.

Zinc. MF had a significant effect on $\mathrm{Zn}$ $(P<0.05)$ concentration in the stem, by which $\mathrm{Zn}$ accumulation was decreased by MF exposure. The interaction between the $\mathrm{Ca}: \mathrm{Mg}$ ratio and mycorrhizae amendment had a significant $(P<0.05)$ effect on $\mathrm{Zn}$ accumulation in the stem. Application of EP$\mathrm{Ca}: \mathrm{Mg}$ in the nutrient solution amended with mycorrhizae increased $\mathrm{Zn}$ accumulation in the stem in comparison with all other treatments considered in this study (Table 3 ).

Copper. The interaction between the $\mathrm{Ca}: \mathrm{Mg}$ ratio, $\mathrm{MF}$, and mycorrhizal amendment had a significant $(P<0.01)$ effect on $\mathrm{Cu}$ accumulation in the stem. Table 3 shows that a High-Ca:Low-Mg ratio together with $0 \mathrm{MF}$ and $20 \mathrm{~mL}$ of mycorrhizae per plant, as well as with $1 \mathrm{MF}$, increased the level of $\mathrm{Cu}$ in the same way as an EP-Ca:Mg ratio of 4.31:4.39 meq. $\mathrm{L}^{-1}$ without MF but with mycorrhizal amendment (Table 3).

\section{Leaf mineral composition}

Magnesium. The ratio of $\mathrm{Ca}$ to $\mathrm{Mg}$ had a significant $(P<0.01)$ effect on the concentration are shown in Table 3. 
$\pi \pi$$$
\text { (2) }
$$

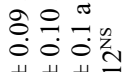
HHH

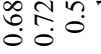

\section{$n$
0
0
0
0
0
0
0}

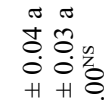

กำ

$\because 0: 0.0 \% \frac{0}{0}$

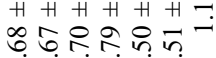

पु०

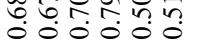

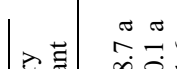

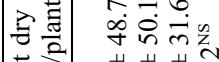

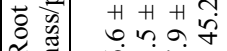

क्षि

西

辛

字字出

+ में

동

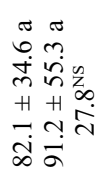

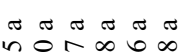

ทे

가에

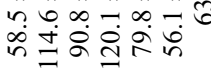

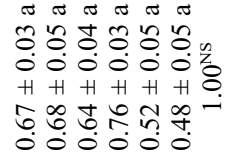

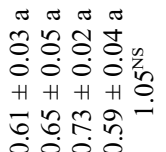

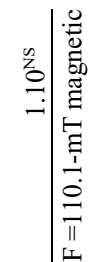

คำก

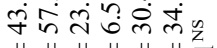

H H H H H H

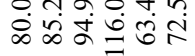

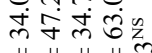

H H H H H

लंखें

$\sin \pi$

$\pi \pi$

$+1+H$

an

H H

กึ

in

$=2$

롱ำ

$\stackrel{\infty}{=} \stackrel{m}{0}^{m}$

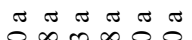

๑̛ं

H H H H H H

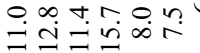

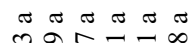

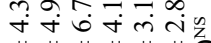

H H H H H HO

ตे

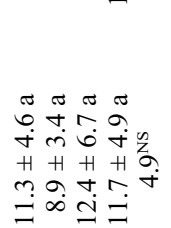

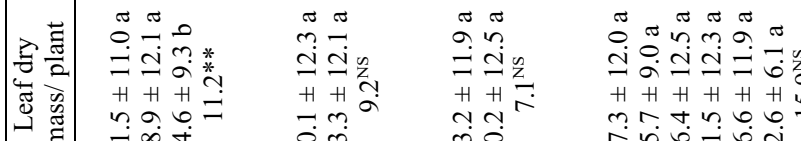

mi்

कें

लें

तิ

高

$\frac{1}{2}+\frac{1}{4}$

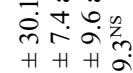

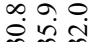

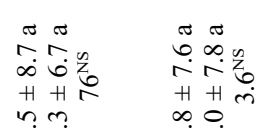

तुल

品市

.

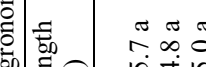

행

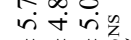

$\begin{array}{lll}+1 & +1 & \\ 0 & 0 & 0\end{array}$

ते

辛光*

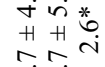

ส่

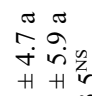

$\begin{array}{lll}+1 & 4 \\ 0 & \infty & m\end{array}$

ते

F.

+

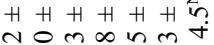

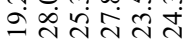

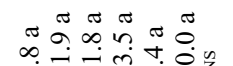

$\infty=\dot{\prime}=\dot{\sigma}$

H H H H H

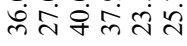

ก)

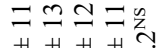

H H H H

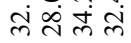

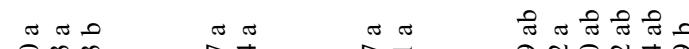

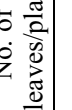

0 m. m

$+1+\frac{1}{1}$

ใิ

in

H H

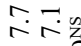

in $\mathrm{H}$ के

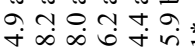

H H H H H H

กำ ํํำ

กั่

तิ

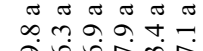

a

H H H H H H

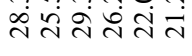

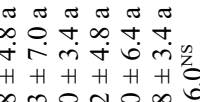

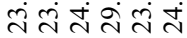

$\pi \pi \pi \pi \pi$

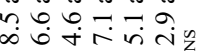

$\mathrm{H}+\mathrm{H}+\mathrm{H}+\mathrm{H}$.

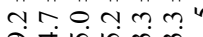

จิปั่

ขึत

สิ่

感

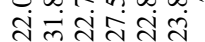

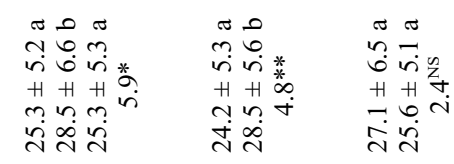

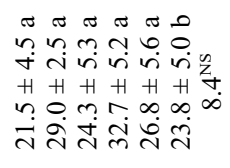

$\pi \pi \theta \pi \theta \pi$

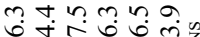

H H H H H H

ปัن

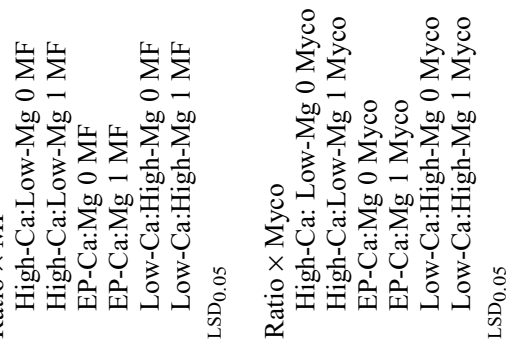

요 $\pi \pi$

लin

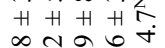

กิ่ิ่ิ

ก̦

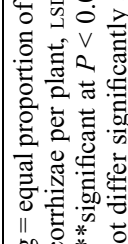

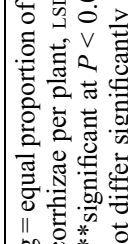

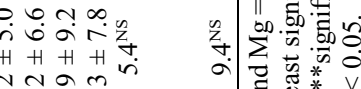

ปั่

ن

$\sum_{i=0}^{\infty} \overbrace{}^{*}$

远

$\pi \pi \pi \pi$

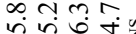

$+H+H$

$\checkmark 0 \infty \mathrm{Nm}$

ปேं ํํำ

되요

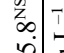

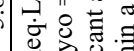

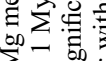

$\sum_{0}-\frac{5}{\infty}$

iิ

$\infty$ D $V$

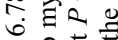

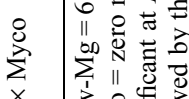

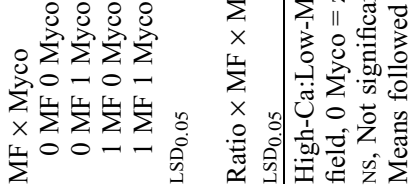

HortScience Vol. 54(10) OCtober 2019 


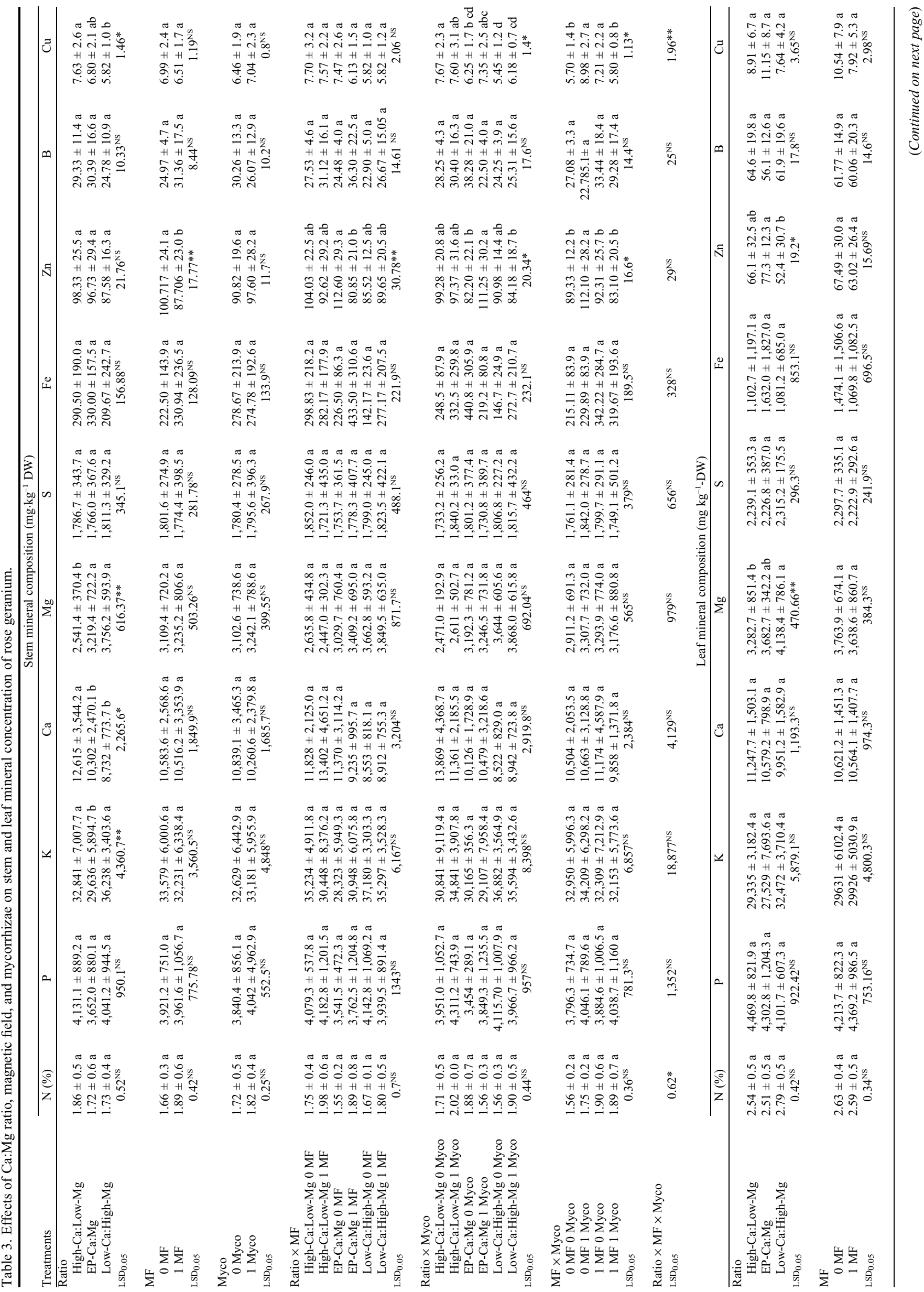




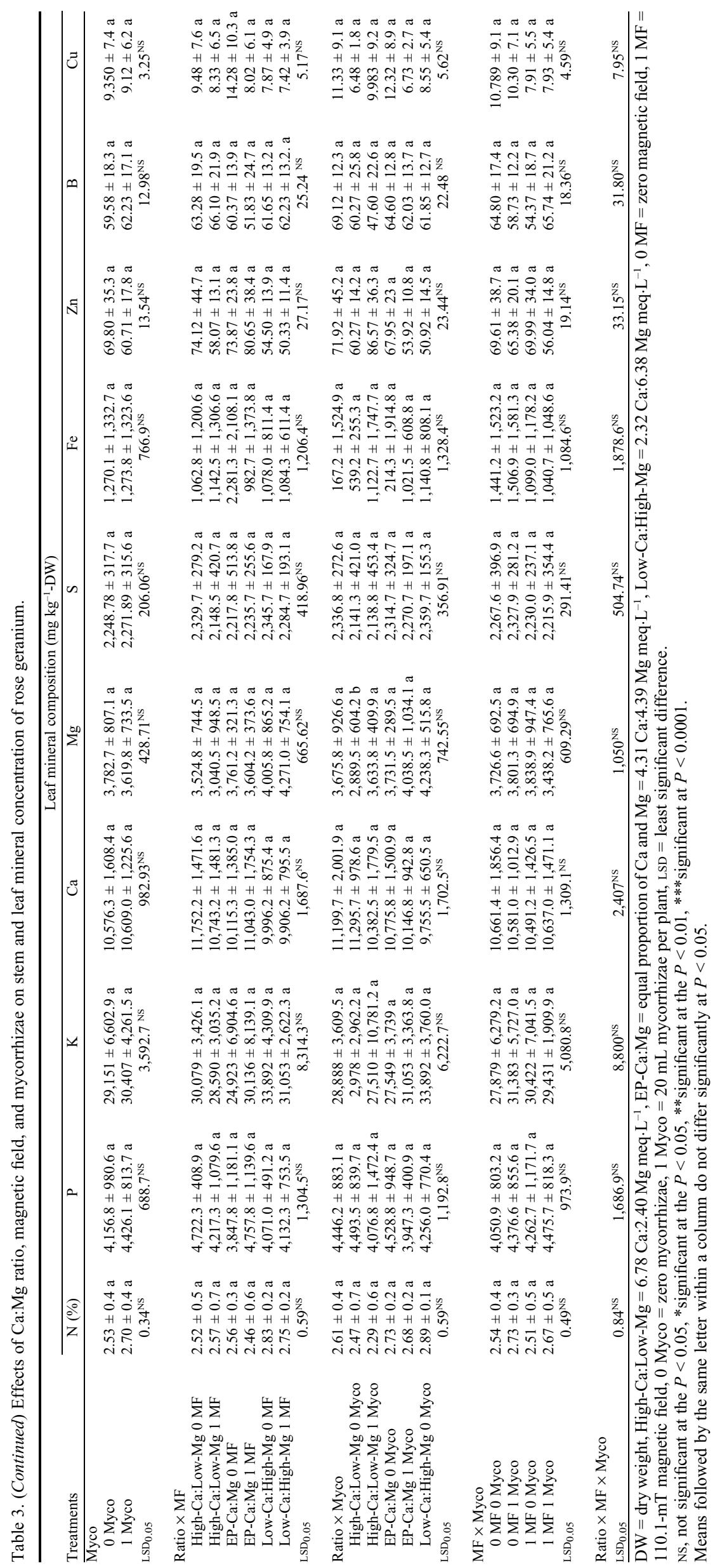

of $\mathrm{Mg}$ in the leaves of rose geranium (Table 3 ). $\mathrm{Ca}$ and $\mathrm{Mg}$ applied at a ratio of 2.40:6.78 meq. $\mathrm{L}^{-1}$ resulted in a greater concentration of $\mathrm{Mg}$ in the leaves but not a significantly different $\mathrm{Mg}$ concentration was obtained when equal proportion of $\mathrm{Ca}: \mathrm{Mg}$ was used in the nutrient solution. It is evident that the concentration of $\mathrm{Mg}$ in the leaves decreased significantly with a Low-Mg:High-Ca ratio in the nutrient solution, whereas a High-Mg:Low-Ca ratio and EP-Ca and $\mathrm{Mg}$ in the nutrient solution resulted in significant increases in the $\mathrm{Mg}$ concentration in the leaves.

Zinc. Although there was no significant effect of the $\mathrm{Ca}: \mathrm{Mg}$ ratio on the leaf $\mathrm{B}, \mathrm{Fe}$, or $\mathrm{Cu}$ contents, a significant effect of the $\mathrm{Ca}: \mathrm{Mg}$ ratio on the leaf $\mathrm{Zn}$ content was detected $(P<$ 0.05 ). Equal proportions of $\mathrm{Ca}$ and $\mathrm{Mg}$ in the nutrient solution significantly increased $\mathrm{Zn}$ concentration in the leaves in comparison with the two ratios considered in this study, LowCa:High-Mg and High-Ca:Low-Mg (Table 3).

\section{Discussion}

It was a hypothesis of this study that High$\mathrm{Ca}: \mathrm{Low}-\mathrm{Mg}$ ratio, MF exposure, and amendment with mycorrhizae has a significant effect on growth and mineral composition of rose geranium. Application of $\mathrm{Ca}$ and $\mathrm{Mg}$ in approximately equal proportions of 4.31 and $4.39 \mathrm{meq} \cdot \mathrm{L}^{-1}$ had significant effects on leaf $\mathrm{Zn}$ and stem $\mathrm{Mg}$ content. The application of $\mathrm{Ca}$ and $\mathrm{Mg}$ in equal proportions and in combination with either an MF or mycorrhizae had significant effects on plant height, chlorophyll content, stem-N, stem $\mathrm{Cu}$, and stem $\mathrm{Zn}$ contents. Steiner's universal solution provided 9.00 and $4.00 \mathrm{meq} \cdot \mathrm{L}^{-1}$ for $\mathrm{Ca}$ and $\mathrm{Mg}$, respectively, contributing to $45 \%$ and $20 \%$ of the total cations (Combrink, 2013). Most of the nutrient solutions developed after Steiner's solution was developed have $\mathrm{Ca}: \mathrm{Mg}$ ratios close to $3: 1$, even though these concentrations are adjusted to suit specific crop requirements (Combrink, 2013). In this study, the best growth was found with a $\mathrm{Ca}: \mathrm{Mg}$ ratio close to $1: 1$. Because most greenhouse crops are grown with $\mathrm{Ca}: \mathrm{Mg}$ ratios of $\approx 3: 1$, this may be an indication that rose geranium needs relatively high levels of $\mathrm{Mg}$.

Various studies have shown a positive relationship between chlorophyll and the $\mathrm{N}$ content of plant leaves (Scheepers et al., 1992; Wang et al., 2004). The chlorophyll content is used as an alternative measure of the nitrogen status of most plant species (Fontes and de Araujo, 2006; Sedibe and Allemann, 2013). The accumulation of $\mathrm{N}$ observed in this study in the case of equal proportions of $\mathrm{Ca}$ and $\mathrm{Mg}$, as well as with high $\mathrm{Ca}$ and low $\mathrm{Mg}$ in combination with no MF or mycorrhizae, could be attributable to the beneficial effect of mycorrhizae or an $\mathrm{MF}$, which are said to improve root structure and $\mathrm{N}$ assimilation (Brady and Weil, 2002; Hozayn et al., 2016; Tisdale, et al., 1993). An MF affects the biochemical processes of plants that control free radicals. MF gradients activate phytohormones, such as gibberellic 


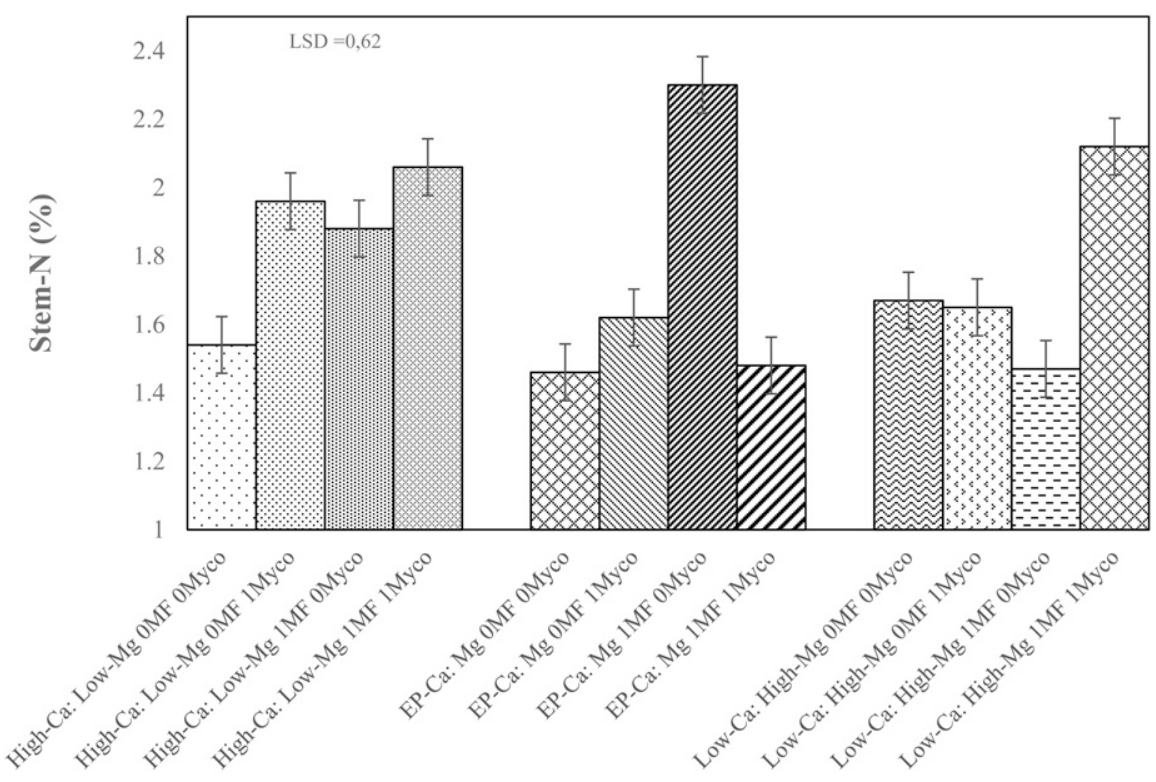

Fig. 1. Effect of the interaction between $\mathrm{Ca}: \mathrm{Mg}$ ratio, magnetic field, and mycorrhizae on stem-N concentration of rose geranium. High-Ca:Low-Mg $=6.78 \mathrm{Ca}: 2.40 \mathrm{Mg}$ meq. $\mathrm{L}^{-1}$, EP-Ca:Mg $=$ equal proportion of $\mathrm{Ca}$ and $\mathrm{Mg}=4.31 \mathrm{Ca}: 4.39 \mathrm{Mg}$ meq $\cdot \mathrm{L}^{-1}$, Low-Ca:High-Mg $=2.32 \mathrm{Ca}: 6.38 \mathrm{Mg}$ meq $\cdot \mathrm{L}^{-1}, 0$ $\mathrm{MF}=$ zero magnetic field, $1 \mathrm{MF}=110.1-\mathrm{mT}$ magnetic field, $0 \mathrm{Myco}=$ zero mycorrhizae, $1 \mathrm{Myco}=20$ $\mathrm{mL}$ mycorrhizae per plant. Vertical lines on bars represent SE $(\mathrm{n}=3)$.

acid, indole-3-acetic acid, and transzeatin, and also activate proteins and enzymes responsible for stem elongation and branching of plants (Hozayn and Qados, 2010; Maheshwari and Grewal, 2009). Increases in root length, root surface area, and root volume have been reported in chickpeas exposed to an MF of $250 \mathrm{mT}$ (Vashisth and Nagarajan, 2008). Under the same conditions, sunflower seedlings have exhibited greater seedling dry mass, root length, root surface area, and root volume (Vashisth and Nagarajan, 2010).

The beneficial effects of applying $\mathrm{Ca}$ and $\mathrm{Mg}$ in approximately equal proportions were observed in this study regardless of whether it interacted with an MF or mycorrhizae. Furthermore, High-Ca and Low-Mg (6.78:2.40 meq. $\left.\mathrm{L}^{-1}\right)$ in the nutrient solution significantly reduced the concentration of $\mathrm{Mg}$ in the leaves. Spiers and Braswell (2002) reported observing an increase in leaf $\mathrm{Ca}$ and a decrease in leaf $\mathrm{Mg}$ as a result of $\mathrm{Ca}$ application to blueberry plants. They also observed that increasing $\mathrm{Mg}$ fertilization resulted in increased leaf $\mathrm{Mg}$ content and decreased leaf $\mathrm{Ca}$ and leaf K (Spiers and Braswell, 2002). However, Shaul (2002) postulated that the $\mathrm{Mg}$ concentrations in different parts of a plant could be small, depending on the amount of $\mathrm{Mg}$ in the soil, the plant growth stage, and water stress. Kadir et al. (2004) found that a low application dose of $\mathrm{Mg}(<2 \%)$ reduced leaf concentration. However, no deficiency symptoms of $\mathrm{Ca}$ and $\mathrm{Mg}$ were observed when $\mathrm{Mg}$ and $\mathrm{Ca}$ were both added at lower doses (White, 2001).

On the other hand, a ratio of High-Ca to Low-Mg in the nutrient solution caused a small increase in the $\mathrm{Zn}$ concentration in comparison with that resulting from a ratio of High-Mg:Low-Ca ratio in the nutrient

sugu (1987) reported that increased Ca in the nutrient solution significantly reduced $\mathrm{Zn}$ absorption and drastically inhibited the translocation of zinc. However, there was no significant relation between the $\mathrm{Ca}: \mathrm{Mg}$ ratio with $0 \mathrm{MF}$ and without mycorrhizae use.

$\mathrm{Ca}: \mathrm{Mg}$ ratio, $\mathrm{MF}$, and $\mathrm{Myco}$ did not significantly affect oil yield of rose geranium, although equal proportions of $\mathrm{Mg}$ and $\mathrm{Ca}$ with $1 \mathrm{MF}$ and mycorrhizae use had a significant effect on the numbers of leaves per plant, leaf, stem, and the dry mass of the root (Table 3 ). However, summer savory oil content was increased by the application of calcium carbonate (Mumivand et al., 2011) and oil yield of oregano increased by $31 \%$ by the application of calcium and magnesium (Dordas, 2009).

\section{Conclusion}

The results of this study show that neither combinations of high $\mathrm{Ca}$ and low $\mathrm{Mg}$ nor low $\mathrm{Ca}$ and high $\mathrm{Mg}$ in the nutrient solution, together with mycorrhizae amendment, contribute to increased oil yield and mineral accumulation within rose geranium plants. However, agronomic attributes (plant height and chlorophyll content) and mineral composition (stem-N) were optimized when approximately equal proportions of $\mathrm{Ca}$ and $\mathrm{Mg}$ were applied in combination with exposure to an MF. This treatment can be useful in the production of rose geranium by enhancing the growth and mineral utilization of this crop.

Abdel-Rahman, S.A.A., A.A.S. Abdel-Kader, and S.E. Khalil. 2011. Response of three sweet basil cultivars to inoculation with (Bacillus subtilis) and (Arbuscular mycorrhizal) fungi under salt stress conditions. Nat. Sci. 9:93-111.
Al-Karaki, G.N. 2000. Growth of mycorrhizal tomato and mineral acquisition under salt stress. Mycorrhiza 10:51-54.

Alveiro, S.J., A.D. Timothy, and R. William. 2017. Horwath nitrogen use efficiency of coffee at the vegetative stage as influenced by fertilizer application method. Fron. Plant Sci. 8:223.

Araya, H.T. 2012. Rose geranium (Pelargonium spp) herbage yield, essential oil yield and composition as influenced by nitrogen nutrition liming. Univ. Pretoria, Pretoria, South Africa, PhD Diss.

Araya, R., J. Jiang, K.B. Eisenthal, and R. Yuste. 2006. The spine neck filters membrane potentials. Proc. Natl. Acad. Sci. USA 103:1761-1766.

Brady, N.C. and R.R. Weil. 2002. The nature and properties of soils. 13th ed. Prentice-Hall Inc., Upper Saddle River, NJ.

Cakmak, I. and E.A. Kirkby. 2008. Role of magnesium in carbon partitioning and alleviating photo oxidative damage. Plant Physiol. 133: 692-704

Chen, J.M. and T.A. Black. 1992. Defining leaf area index for non-flat leaves. Agr. For. Meteorol. 57:1-12.

Combrink, N.J.J. 2013. Mixing a balanced nutrient solution. Acta Hort. 1014:13-27.

Dordas, C. 2009. Foliar application of calcium and magnesium improves growth, yield, and essential oil yield of oregano (Origanum vulgare ssp. hirtum). Ind. Crops Prod. 29(2-3):599-608.

Etheridge, D.M., L.P. Steel, R.J. Francey, and R.L. Langenfelds. 1998. Atmospheric methane between 1000 A.D and present: Evidence of anthropogenic emissions and climatic variability. J. Geophys. Res. 103(D13):15,979-15,993.

\section{Literature Cited}

Hozayn, M. and A.M.S.A. Qados. 2010. Magnetic water application for improving wheat (Triticum aestivum L.) crop production. Agr. Biol. J. N. Amer. 1(4):677-682.

Hozayn, M., M.M. Abdallha, A.A. Abd El-Monem, A.A. El-Saady, and M.A. Darwin. 2016. Applications of magnetic field technology in agriculture: A novel tool for improving crop production. Afr. J. Agr. Res. 11(5):441-446.

Jeffries, P., S. Gianinazzi, S. Perotto, K. Turnau, and J.-M. Barea. 2003. The contribution of arbuscular mycorrhizal fungi in sustainable maintenance of plant health and soil. Biol. Fertil. Soils 37(1):1-16.

Ju, X. and P. Christie. 2011. Calculation of theoretical nitrogen rate for simple nitrogen recommendations in intensive cropping systems: A case study on the North China Plain. Field Crops Res. 124:450-458.

Kadir, T., A. Zisserman, and M. Brady. 2004. An affine invariant salient region detector. Proc. 8th Eur. Conf. Comp. Vis., Prague, Czech Republic. 345-457.

Kawasaki, T. and M. Moritsugu. 1987. Effect of calcium on the absorption of heavy metals in excised barley roots: Multi-compartment transport box experiment. Plant Soil 100:21-34.

Kordas, L. 2002. The effect of magnetic field on growth, development and the yield of spring wheat. Pol. J. Environ. Stud. 11(5):527-530.

Maheshwari, B.L. and H.S. Grewal. 2009. Magnetic treatment of irrigation water: Its effects on vegetable crop yield and water productivity. Agr. Water Mgt. 96:1229-1236.

Matejovič, I. 1996. The application of Dumas method for determination of carbon, nitrogen, and sulphur in plant samples. Rostlinna Vryroba. 42(7):313-316.

Mengel, K. and E.A. Kirkby. 2004. Principles of plant nutrition. Ann. Bot. 93(4):479-480.

Mumivand, H., M. Babalar, J. Hadian, and M. Fakhr-Tabatabaei. 2011. Plant growth and essential oil content and composition of saturn 
(Satureja hortensis L.) in response to calcium carbonate and nitrogen application rates. J. Med. Plants Res. 5(10):1859-1866.

Occhipinti, A., A. De Santis, and M.E. Maffei. 2014. Magnetoreception: An unavoidable step for plant evolution? Trends Plant Sci. 19(1):1-4.

Patel, J.S., A. Singh, H.B. Singh, and B.K. Sarma. 2015. Plant genotype, microbial recruitment and nutritional security. Front. Plant Sci. 6:608.

Fontes, P.C.R. and C. de Araujo. 2006. Use of a chlorophyll meter and plant visual aspect for nitrogen management in tomato fertigation. J. Appl. Hort. 8(1):8-11.

Sander, M.L. and O. Andren. 1997. Ash from cereal and rape straw used for heat production: Liming effect and contents of plant nutrients and heavy metals. Water Air Soil Pollut. 93(1-4): 93-108.

Scheepers, J.S., D.D. Francis, M. Vigil, and F.E. Below. 1992. Comparison of corn leaf nitrogen concentration and chlorophyll meter readings. Commun. Soil Sci. Plant Anal. 23:17-20, 2173-2187.

Sedibe, M.M. 2012. Yield and quality response of hydroponically grown rose geranium (Pelargonium spp.) to changes in the nutrient solution and shading. Univ. Free State, Bloemfontein, South Africa, PhD Diss.

Sedibe, M.M. and J. Allemann. 2012. Yield and quality response of rose geranium (Pelargo- nium graveolens L.) to sulphur and phosphorus application. South African J. Plant Soil 29(34):151-156.

Sedibe, M.M. and J. Allemann. 2013. Yield and mineral response of rose geranium (Pelargonium graveolens L.) to phosphorus and two irrigation methods. Life Sci. J. 10(3):884-888.

Shaul, O. 2002. Magnesium transport and function in plants: The tip of the iceberg. Biometals. 15:309-323.

Spiers, J.M. and J.H. Braswell. 2002. Influence of $\mathrm{N}, \mathrm{P}, \mathrm{K}, \mathrm{Ca}$, and $\mathrm{Mg}$ rates on leaf macronutrient concentration of 'Navaho' blackberry. Acta Hort. 585:659-663.

Steel, R.G.D. and J.H. Torrie. 1980. Principles and procedures of statistics: A biometrical approach. 2nd ed. McGraw-Hill, NY.

Tisdale, S.L., W.L. Nelson, J.D. Beaton, and J.L. Havlin. 1993. Soil fertility and fertilisers. 5th ed. Macmillan Publishing Co., NY.

Vanderstraeten, J. and H. Burda. 2012. Does magneto reception mediate biological effects of power-frequency magnetic fields? Sci. Total Environ. 417:299-304.

Vashisth, A. and S. Nagarajan. 2008. Exposure of seeds to static magnetic field enhances germination and early growth characteristics in chickpea (Cicer arietinum L.). Bioelectromagnetics 29:571-578.
Vashisth, A. and S. Nagarajan. 2010. Effect on germination and early growth characteristics in sunflower (Helianthus annuus) seeds exposed to static magnetic field. J. Plant Physiol. 167:149-156.

Wang, Q., J. Chen, and Y. Li. 2004. Nondestructive and rapid estimation of leaf chlorophyll and nitrogen status of peace lily using a chlorophyll meter. J. Plant Nutr. 27:557-569.

Welch, R.M., W.A. Norvell, S.C. Schaefer, J.E. Shaff, and L.V. Kochian. 1993. Induction of iron (III) and copper (II) reduction in pea (Pisum sativum $\mathrm{L}$.) roots by $\mathrm{Fe}$ and $\mathrm{Cu}$ status: Does the root-cell plasmalemma $\mathrm{Fe}$ (III)chelate reductase perform a general role in regulating cation uptake? Planta 190:555-561.

White, P.J. 2001. The pathways of calcium movement to the xylem. J. Expt. Bot. 52:891-899.

White, P.J. and M.R. Broadly. 2003. Calcium in plants. Ann. Bot. 92:487-511.

Yousaf, M., J. Li, J. Lu, T. Ren, R. Cong, S. Fahad, and X. Li. 2017. Effects of fertilization on crop production and nutrient-supplying capacity under rice-oilseed rape rotation system. Sci. Rep. 12(7): 1270 .

Zhang, C. and R. Turgeon. 2009. Downregulating the sucrose transporter VpSUT1 in (Verbascum phoeniceum) does not inhibit phloem loading. Plant Biol. 106(44):18849-18854. 